\title{
Urihi A: A Terra-Floresta Yanomami
}

Bruce Albert and William Milliken with Gale Goodwin Gomez. São Paulo: Instituto Socioambiental, 2009. 207 pp., illustrations, tables, bibliography, appendices, index. Paperback ISBN: 978-85-85994-72-3.

\author{
Reviewed by James R. Welch ${ }^{1}$
}

Reviewer Address: ${ }^{1}$ Escola Nacional de Saúde Pública, Fundação Oswaldo Cruz, Rio de Janeiro

Received: March $30^{\text {th }} 2010$

Published: August $15^{\text {th }} 2010$
Volume 1:18-19

(C) 2010 Society of Ethnobiology

discusses Yanomami ethnobotany in the context of other publications on ethnobotany in Amazonia.

Ethnobotanical knowledge among contemporary indigenous groups in Amazonia is rarely as tidy as it would appear to be when presented in lists and tables. Albert and Milliken make no mistake of that fact, opting to present their methods with integrity and honesty in light of the complex realities of Yanomami plant knowledge. For example, they address in a straight-forward manner the tendencies, typical of Amazonian ethnobiological systems, for high degrees of temporal and spatial variation, individual or idiosyncratic knowledge, as well as the operational difficulties of uncertainty and recall error. They deal with these challenges creatively but systematically. For example, they favored the deliberation of responses by Yanomami collaborators through group interviews and only recorded responses supported by consensus. Additionally, the authors made plant collections with proper ethnobotanical procedures. Botanical identifications were made by specialists at national and foreign herbariums, including the Royal Botanic Gardens, Kew, the New York Botanical Gardens, the National Institute of Amazon Research (INPA), and the Integrated Museum of Roraima. Given these methods, their data appear to have a high degree of reliability and their limits are clearly delineated.

The text also benefits from a strong diachronic emphasis even though the study was not explicitly intended to be historical ecological. The Yanomami population is large and diverse with an accordingly complex early history. Recent Yanomami history includes non-indigenous encroachment accompanied by dramatic sociocultural, demographic, and ecological transformations. The authors insightfully discuss Western Yanomami ethnobotany in light of this historical setting, elucidating its temporal dimensions in a manner that transmits the dynamic realities by which 
traditional environmental knowledge transforms through time. In this respect, the book benefits from data collected at different moments in time and in communities located in different environmental settings. It also benefits from special attention to the difference between contemporary usages and those from prior decades that were recalled by elders. The authors communicate these complexities with clarity, always attending to the humanness of the Yanomami in specific historical, sociocultural, and ecological settings.

Written in a conversational style, Albert and Milliken emphasize expository writing rather than plant inventories (although the authors provide abundant tables), this book is both a pleasure to read and an informative resource. It successfully manages to present botanical data in systematic fashion while affording ample space for more anthropological topics, such as architecture, female healing practices, and cosmology. In these instances, as well as others, the authors provide rich ethnobotanical detail for cultural domains that do not always receive such thorough attention. For example, the prevalent and apparently traditional Yanomami roof construction employing leaves from the palm Geonoma baculifera bound to splints made from Socratea exorrbiza is shown to be a historical borrowing from non-Yanomami indigenous workers at a federal Indian Protection service (SPI) post operating in the region during the 1940s. Previously, the more common roofing material was leaves of a different palm, Geonoma deversa, bound with a vine in the genus Heteropsis.

Organizing the book by use categories rather than by botanical taxa was also instrumental in the authors' effort to be informative without usurping Yanomami control over their intellectual property. In this effort the authors should be congratulated. Make no mistake, attending to the ethical and legal imperative that science should not violate the rights of a study population or host country is tricky business. In this case, it appears that the study was conducted with necessary permissions from the National Indian Foundation (FUNAI) and the Brazilian Research Council (CNPq). Furthermore, the authors adopted the measure of excluding uniquely Yanomami ethnomedicinal data, opting instead to publish only Yanomami plants and their uses that are similar to those already documented for other indigenous Amazonian groups. This measure is ethically appropriate because it allows the Yanomami to retain control over their unique ethnomedicinal knowledge. Despite that limitation, the book remains highly informative by emphasizing cultural and historical dimensions of plant knowledge in addition to botanical identifications. This is especially apparent in the domains of cosmology and mythology, where the authors aptly demonstrate the interconnectedness of the physical, metaphysical, and historical dimensions of ethnobotanical knowledge.

As one of the precious few rigorous and relevant ethnobotanical publications to come from Brazil in recent years, Uribi A: A Terra-Floresta Yanomami is an important resource for scholars and nonspecialists. It is also recommended for students interested in an example of responsible ethnobiological research in Brazil. 